The Effect of Corruption and Anti-Corruption on Firm Performance Dr. HEBA KAMAL ELQASSABY ATALLAH

\title{
The Effect of Corruption and Anti-Corruption on Firm Performance
}

\section{Dr. HEBA KAMAL ELQASSABY ATALLAH}

Lecturer of Business Administration in Delta Higher Institute for Computers, Delta Academy of science and Technology

\begin{abstract}
The research aimed to investigate the effects of corruption and anti-corruption on firm performance. The data of the research was collected from participants who work in a private international school group in Dhahran city in Saudi Arabia, this research was applied to a sample of 200 employees. The result of the study has indicated that there is a significant low relationship between corruptions and firm performance, the results also indicated that there was a significant strong relationship between anti-corruption and firm performance. and the results showed that there is no significant effect of corruption on Firm performance while there is a strong significant effect of ant-corruption on firm performance. The research has recommended that managers and officials should invest more time in anti-corruption awareness, and try to control corrupted behaviors, finally implement an effective system to help both managers and employees avoid any related corruption behaviors.
\end{abstract}

Keywords: Corruption - Anti-corruption - Firm performance. 
The Effect of Corruption and Anti-Corruption on Firm Performance

Dr. HEBA KAMAL ELQASSABY ATALLAH

\section{ملخص}

يهدف البحث إلى دراسة تأثير الفساد ومكافحة الفساد على أداء الثركات. تم

جمع بيانات البحث من مشاركين يعملون في مجمو عة مدارس دولية خاصة في مدينة

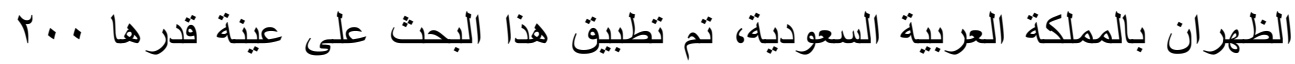

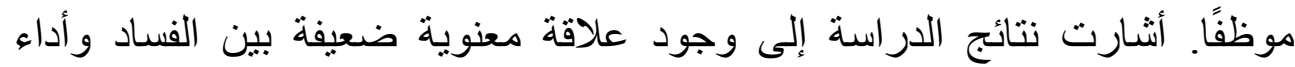

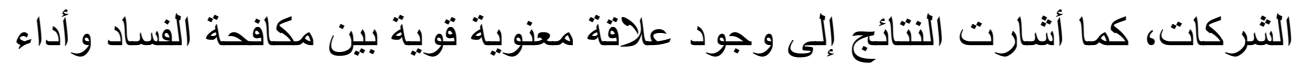

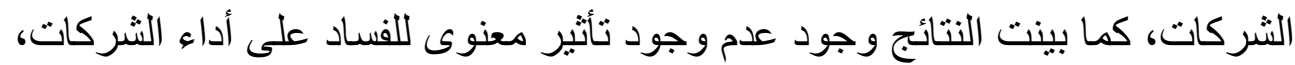

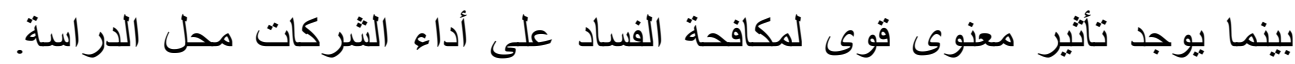

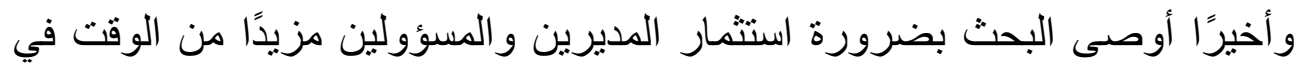

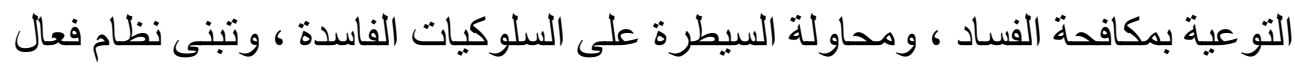
لمساعدة كل من المديرين والموظفين على تجنب أي سلوكيات لها صلة بالفساد.

كلمات مفتاحية: الفساد - مكافحة الفساد ـ أداء الثركات

\section{INTRODUCTION}

Corruption is a subject that is difficult to define and it's difficult to find a precise definition of it. (Myint, 2000) described corruption as "an act in which the power of public office is used for personal gain in a manner that contravenes the rules of the game". There are different types of corruption that even in their simple forms can influence government policy. These types are: first, corruption of having specific rights that are entitled to citizens or speeding up the process of having some rights. Second, corruption of violating legal regulations and it called administrative corruption and its one of the most popular type of 
The Effect of Corruption and Anti-Corruption on Firm Performance

Dr. HEBA KAMAL ELQASSABY ATALLAH

corruption. Finally, state capture corruption where the corruptor changes the regulation to meet his interest. There are different causes of corruption: low motivation, weak legislative and punishment system, lack of transparency, lack of accountability (Ugaz \& Panfilova, 2016).

Anti-corruption agencies (ACAs) are key to the fight against corruption. As of June 2018, the United Nations Convention Against Corruption has 186 parties signed. The Convention covers five main areas: preventive measures, criminalization and law enforcement, international cooperation, asset recovery, and technical assistance and information exchange. The Convention covers many different forms of corruption, such as bribery, trading in influence, abuse of functions, and various acts of corruption in the private sector (United Nations convention against corruption, 2018). The Kingdom of Saudi Arabia has established the anti-corruption commission in 2015 and its main role is Working on protecting the integrity and combating corruption in the kingdom to create a work environment of integrity, transparency, honesty, justice, and equality.

Firm performance is a term which relates to the organization performance, organization functions, and organization's operation outcomes. Basically, Firm performance used as an important measure for firm's efficiency. It's a critical indicator which investors and stakeholders used to value a firm 
The Effect of Corruption and Anti-Corruption on Firm Performance

Dr. HEBA KAMAL ELQASSABY ATALLAH

(Selvam, et. al, 2016). There are several determinants for Firm performance. These indicators are market value performance, growth performance, customer and employees' satisfaction, and social performance. In this paper, we will concentrate on how these determinants can be affected by corruption and the consequences of those effects.

\section{LITERATURE REVIEW}

This section presents theoretical concepts related to the study. It will discuss the corruption, Anti-corruption, Firm performance, and the effects of corruption on Firm performance and the anti-corruption role. This study does not focus on the types and causes of corruption or determinants of Firm performance, but rather focus on the effects and the impacts of corruption on the performance of firms and the role of anticorruption in preventing it.

\subsection{CORRUPTION}

Corruption is one of the obstacles to economic growth, organization success, and social development. It's universal issues that have a significant impact on both public and private firms in developing countries the most. The very known assumption of corruption is that its serious problem which has great economic issues on both its content and its effects (Hindess, 2012). The popular format of corruption is that people are willing to pay for action from people who have control rights. Bribes, nepotism, extortion, and embezzlement are a few types of 
The Effect of Corruption and Anti-Corruption on Firm Performance

Dr. HEBA KAMAL ELQASSABY ATALLAH

corruption. Officials or people in control demand to be corrupted to achieve some materialistic desires. Low level of democracy, low level of press transparency are some causes of corruption. It does not only deteriorate the quality of services it also downgrades the quality of life of a person. (Mone \& London, 2018) stated that "the more widespread and acceptable corrupt methods are in a given society, the more corrupt that society is said to be". Once an individual strengthens their personal power with money or material favor in return, it will be impossible for other to operate through proper channel and being authentic.

The World Bank (2009) defined corruption as one of the greatest obstacles to economic growth, social development, and reduction of poverty.

(Johnston, 1996) called the classical view of corruption as it is a society or a state that has lapsed from a standard of goodness and it can relate to qualities of individual actions.

(Dabbous \& Dimant, 2018) define corruption as the intentional non-compliance with the arm's- length principle aimed at deriving some advantage for oneself or for related individuals from this behavior.

(Pinto \& Pil, 2008) described corruption as dishonest or illegal behavior, especially by the people in official positions. He continued describing corruption as a misused power of the officials while economics largely view corruption as a sand in the 
The Effect of Corruption and Anti-Corruption on Firm Performance

Dr. HEBA KAMAL ELQASSABY ATALLAH

gear of the economy, political scientists view it as the grease in the gear.

(Svensson, 2005) stated that corruption means the practice of obtaining power, influence, or other personal gains through illegitimate means and through abusing authority and power.

(Treisman, 2000) defined corruption as rent-seeking activities and it is an abuse of public power for private benefits. (Treisman, (2000) also defined corruption as the unfair or inequitable transfer of wealth or benefits from the corruptive activities and that a small number of individuals benefited from the act while another group of individuals is determined.

(Sahakyan \& Stiegert, 2012) corruption is using public office for a private gain and its mainly exists as a unilateral opportunity for individual economic agents to enrich themselves through illegal activities.

There are many types of corruption first, grand corruption is illegal acts that occur the most at a higher level of government and it corrupt the polices and the main functions of the country or state giving people in control and power the ability to benefits at the expense of public rights and good. In other words, achieving materialization from abusing the right of a citizen or entity without any legal barriers.

According to the (Ugaz \& Panfilova, 2016), grand corruption is the abuse of high-level power that benefits the few at the expense 
The Effect of Corruption and Anti-Corruption on Firm Performance

Dr. HEBA KAMAL ELQASSABY ATALLAH

of the many and causes serious and widespread harm to individuals and society, it often goes unpunished.

Second, petty corruption and that is everyday corrupted acts which occur at the low-mid government officials who interact with the citizens in organizations like government sectors, private companies, hospitals, and schools. This is the most modeled and critical type of corruption and it violates the legal rules of an entity. Moreover, petty corruption infects the structure of social controls and make the community loses its ability to discriminate against honest and corrupted ethics (Alshamari \& Loai, 2011). Bribes, embezzlement, fraud, abuse of power, and nepotism fall under this type of corruption.

Third, political corruption or state capture corruption. This type was developed by the World Bank to explain the reality of political corruption. This type of corruption manipulates major policies and rules by the political decision maker to allocate resources toward sustaining powers and wealth through abusing their position.

(Dreher, et.al, 2005) found that there are factors which are correlated with corruption. explained some of these factors are a significant contributor to low economic growth, destroy investment, lower the quality of public services, and increase inequality.

First, the organizational structure which permits the people in control to have great freehand on the organization and as result 
The Effect of Corruption and Anti-Corruption on Firm Performance

Dr. HEBA KAMAL ELQASSABY ATALLAH

will have a high level of corruption. This shadowed relationship allows powerful officials to depart from rules and procedures by allocating the resources differently toward their interest when receiving bribes or gifts for instance. Corrupted administrators weaken the ability to promote good and fair practices and professional working environment (Chilton, 2005).

Second, the degree of competition is one of the critical causes of corruption. Industries which have a higher degree of competition is associated with lower level of corruption. Firms that acknowledged their competitors relatively expected to deliver the highest quality of services to their customers.

(Rose-Ackerman,1998) stated that "In general, any reform that increases the competitiveness of the economy will reduce incentives for corrupt behavior."

Third, rule of law and strict judicial system are very important in lowering the level of corruption. Treisman (2000) explained that "when there is a penalty against corruption acts there is less incentive to do so". Countries which have active anti-corruption legislation will probably have less corruption in its organizations.

Fourth, low motivation such as low pay scale and low job opportunity are other causes of corruption in the developing countries (World Bank, 2009). Wages disparity between public and private sectors are usually associated with higher level of corruption. Government employees tend to receive lower salaries 
The Effect of Corruption and Anti-Corruption on Firm Performance

Dr. HEBA KAMAL ELQASSABY ATALLAH

than employees of private sectors. This has encouraged employees to go with a corrupted act for more financial benefits. Lack of job opportunity is another cause of corruption (RoseAckerman, 1998).

Fifth, according to (Ugaz \& Panfilova, 2016)) lack of accountability and transparency are among the causes of corruption. Lack of mandate for tasks will increase the rate of uncompleted tasks within a given time frame. Unaccountable employees are associated with higher level of corruption. The beneficiaries will have to pay for the urge of transactional clearance. Same is for lack of transparency and a higher level of corruption when the organization fails to show the mechanisms and the framework used to prevent corruption.

Lambsdorff (2005) investigated some critical consequence of corruption. He stated that "As corruption increases the risks associated with making investments by lowering the security of property rights, economic theory predicts that corruption will have a clear negative impact on the ratio of investment to GDP."

Inequality is another consequence of corruption. There is a clear relationship between corruption and inequality; corruption increases inequality and inequality escalating corruption to impact social norms and intolerance (Lambsdroff, 2005).

According to (Enste \& Heldman, 2018), there is a strong significant decrease in the quality of government service and the trust in civil servants is significantly lower in countries with a 
The Effect of Corruption and Anti-Corruption on Firm Performance

Dr. HEBA KAMAL ELQASSABY ATALLAH

high level of corruption. The lack of trust in the civil service can lead to a destabilization of the country because the legitimacy of the political authority is challenged.

\subsection{ANTI-CORRUPTION}

According to The World Bank- Combating corruption (2018), corruption is one of the major challenges and has disproportionate impacts. The goal of the bank along with UNsustainable development goals and financing for development is to combat the corruption impacts by 2030. Successful anticorruption practice required attention from governments and business and the use of advanced technology to track, analyze, and share significant data to detect, prevent and stop corrupted behaviors.

According to the United Nation Global Compact (2018), The 10th Principle of the UN Global Compact states that "Businesses should work against corruption in all its forms, including extortion and bribery." Anti-corruption has collective action that allows the organization to have a deeper understanding of corruption problems. Also, it combines knowledge, financial, and technical recourses to achieve higher impact. Another benefit of anti-corruption is creating a stable productive business environment as well as provide credible, acceptable, and sustainable solutions. These collective action forms are, integrity pacts, anti-corruption declarations, certifying 
The Effect of Corruption and Anti-Corruption on Firm Performance

Dr. HEBA KAMAL ELQASSABY ATALLAH

business coalitions, principle-based initiatives, and education and training.

(Alshamary \& Loai, 2011) explained that there are four main mechanisms that are associated with anti-corruption: responsibility, accountability, transparency, and integrity. These four mechanisms play an important role in preventing corruption and limit its effects. Such a mechanism will ensure having organizations with legal, administrative, and moral accountability.

The National Anti- Corruption Commission of Saudi Arabia (Nazaha) which was established in 2012 to be among the international distinguished commission to protect integrity and combat corruption. The commission values are teamwork, professionalism, innovation, integrity, cooperation, transparency, honesty, and excellence. Most important achievements of the commission in accordance with its jurisdiction set out in its regulations are the effort in protecting the integrity and enhance transparency, the effort in combating corruption, and the effort at the international level including representing the kingdom at international conferences and forums related to anti-corruption.

According to (Bertot, et.al, 2010), there are three traditional approaches of anti-corruption: Administrative Reform, Law Enforcement, and Social Change. First, the administrative approach which include the enhancement of the quality of the government to ensure there is an accountable professional 
The Effect of Corruption and Anti-Corruption on Firm Performance

Dr. HEBA KAMAL ELQASSABY ATALLAH

structure to officially monitor government behaviors and administrators in the higher positions. Also, ensure there is a valid merit-based hiring and promoting to feature and formalized rules of conduct, accountability, and responsibility.

Second, law enforcement, this approach help ensures the existence of an appropriate system to increase the cost and the punishment of any corrupted actions such as accepting bribes or practice nepotism.

Third, the social change, it is all about social empowerment of citizens and allowing them to participate in institutional reform movements and by cultivating a civil, lawbased society to combat corruption. Also, changing cultural attitudes that have been accepting of corruption by raising awareness, this will definitely allow citizens to ultimately protect themselves from corruption.

\subsection{FIRM PERFORMANCE}

Firms have an important role in our daily lives and therefore, successful firms represent a key ingredient for developing countries. Many economists consider firms and institutions similar to an engine in determining the economic, social and political progress (Gaverea, et.al, 2007). Firm performance is an indicator for investors and stakeholders. It is a measure if the company or the business is worth the investment or not. The main objective of any firm is to maximize its profit which is driven by revenues and costs. To maximize the profit, it 
The Effect of Corruption and Anti-Corruption on Firm Performance

Dr. HEBA KAMAL ELQASSABY ATALLAH

is very important to look at the structure and the individual behaviors of the firm which then determines their profitability (Adetunji \& Owolabi, 2016). Another fact is that firm performance is used as a measure of the firm's operations efficiency and effectiveness.

(Gaverea, et.al, 2007) stated that "although the concept of organizational performance is very common in the academic literature, its definition is difficult because of its many meanings". For this reason, there isn't a universally accepted definition of this concept.

(S.N.\& Sen, 2017) defined firm performance as a measure of performance of a company that may not only depend on the efficiency of the company itself but also on the market where it operates.

According to (Wongrassamee, et. al, 2003), Firm performance is the power of a business to implement activities better rather than its competitors. they defined the firm performance as the integrated system of the work of the institution in light of its interaction with the elements of its internal and external environment and includes three dimensions as follow: first, The performance of the individual in the organizational unit. Second, the performance of organizational units within the framework of the general policies of the institution. Third, the performance of the institution within the framework of the economic, social and cultural environment. 
The Effect of Corruption and Anti-Corruption on Firm Performance

Dr. HEBA KAMAL ELQASSABY ATALLAH

According to (Lebas \& Euske, 2007) firm performance includes a set of financial and nonfinancial strategic indicators which offer information on the degree of achievement of the goal and objectives.

According to (Selvam, et.al, 2016), listed some identified firm performance determinants. These determinants are financial and strategic performance. Financial performance determinants are profitability performance, market value, and growth while the strategic performance is the satisfaction of employees, customer satisfaction, and social performance.

First, profitability performance shows the ability of the firm to gain a profit. It's any for-profit organization objective to maximize its wealth of the stakeholders. According to (Sivathaasan, et.al, 2013), a business that is not profitable cannot survive. On the other side, a business that is highly profitable has the ability to reward its owners with a large return on their investment. It's very important for a firm to earn a profit in order to achieve sustainability of the business in prevailing market conditions.

Second, market value performance which is a variable that represents the external assessment and expectation of future performance of firms. It is a key concern and the ability to predict stock trends based on information which is publicly disclosed (Selvam, et.al, 2016). According to (Jiménez-Jiménez \& Sanz-Valle, 2011), "What investors believe a firm is worth; 
The Effect of Corruption and Anti-Corruption on Firm Performance

Dr. HEBA KAMAL ELQASSABY ATALLAH

calculated by multiplying the number of shares outstanding by the current market price of a firm's shares". A firm's market value is an excellent indication for investor's perception of its business prospects. Over periods of time, market value can fluctuate a great deal which influenced by the business cycle. It also variable that depends on other factors such as the type of operation, profit, and market environment.

Third, the growth performance is a key to a firm's longterm success. According to (Yusof \& Abu Bakar, 2012) company's growth commonly equated with success and there are various indicators to measure growth performance such as turnover, number of employees, total assets, profits, market capitalization. (Yusof \& Abu Bakar, 2012) conclude that "growing companies have long attracted the attention of policymakers worldwide and high growth enterprises are seen as important contributors to employment, innovation, and competitiveness. Companies that achieve significant growth will lead them to be more active contributors to the nation.

Fourth, employees' satisfaction and that demonstrate how employees are satisfied with their roles and responsibilities, their management, and the work environment. According to (Selvam, et.al, 2016), the employees are the group of people who work toward achieving the firm's' goals and demonstrate the firm values. These employees provided with a clear job description, training, and career plans. For a firm to be successful, it must 
The Effect of Corruption and Anti-Corruption on Firm Performance

Dr. HEBA KAMAL ELQASSABY ATALLAH

invest in human resources and increase its ability to attract employees and decrease the turnover rate in the long term. (Parvin \& Kabir, 2011) stated that" The happier people are within their job, the more satisfied they are said to be. Job satisfaction is not the same as motivation, although it is clearly linked. Job design aims to enhance job satisfaction and performance methods include job rotation, job enlargement, and job enrichment. Job satisfaction is a very important attribute which is frequently measured by organizations. The most common way of measurement is the use of rating scales where employees report their reactions to their jobs". Employees who report high job satisfaction tend to achieve higher productivity. When employees are safe and satisfied can result in higher sales, lower costs and a stronger bottom line.

Fifth, the satisfaction of customers is a performance indicator to measure if a good or a service meet customer expectations. (Singh, 2006) addresses that "to be successful, organizations must look into the needs and wants of their customers. That is the reason why many researchers and academicians have continuously emphasized the importance of customer satisfaction, loyalty and retention". Customer satisfaction can be measured by four metrics: overall satisfaction, loyalty, factor-level satisfaction, and willing to recommend.

Last, the social performance or corporate social performance CSP is another determinant for a firm's 
The Effect of Corruption and Anti-Corruption on Firm Performance

Dr. HEBA KAMAL ELQASSABY ATALLAH

performance. According to (Wood, 1991) CSP can be defined as 'a business organization's configuration of principles of social responsibility, processes of social responsiveness, and policies, programs, and observable outcomes as they relate to the firm's societal relationships. It is essential for any organization to engage socially with the community. It enhances the bottom line performance for an organization. It measures how well the firm has translated its social goals into practice.

Research on firms/ organizational performance on the financial or the operational aspects has revealed different factors that are significantly affecting the performance. According to (Al-Tit, 2017) some of these factors are management skills and charisma, stakeholders' investment and support, intellectual capital, human capital, organizational learning, supply chain innovation, managerial practice related to strategies, performance measurements, and knowledge creation.

According to (Wang, et.al, 2005) the influence of managers' charismatic leadership styles on the team's cohesiveness is very important as it affects the teams' overall performance. Charisma is a process and interaction between the qualities of the leaders, the followers, and their needs. charismatic qualities of leaders, emphasis on how they communicate with their followers and whether they are able to gain followers' trust, and influence and persuade them to follow. (Odusami, 2002) highlighted the importance of five managerial

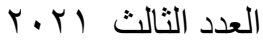

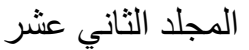


The Effect of Corruption and Anti-Corruption on Firm Performance

Dr. HEBA KAMAL ELQASSABY ATALLAH

skills for successful managers, these skills are managing change, recognizing opportunities, handling problems, decision making, and social skill.

According to (Wongrassamee, et.al, 2003), performance measurements used to maintain and improve the organization's competitive advantages. It's used to evaluate, measure, control, and improve the business process. A balanced scorecard is a strategic planning and management measure widely used by organizations to communicate what they are trying to accomplish, align daily work that everyone is doing with strategy, prioritize projects, products, and services, and measure and monitor progress towards strategic targets.

\subsection{THE RELATIONSHIP BETWEEN CORRUPTION, ANTI-CORRUPTION AND FIRM PERFORMANCE}

According to (Treisman, 2000), officials or people who are in a higher and control positions continue to misuse their power for private gain as a result of two related aspects. First, the absence of a legal system in its degree of protecting the resources, opportunities, or people who get harmed by the corrupted act. Second, enforcement of the legal system that is related to the legal culture of the country or firm.

(Angela, 2016) explained that the "impact of corruption indicates that its effects tend to reverberate throughout an economy rather than be confined to the specific corruption-based transaction". Corruption affects the performance of the 
The Effect of Corruption and Anti-Corruption on Firm Performance

Dr. HEBA KAMAL ELQASSABY ATALLAH

organization, level of investment, enforcement of the rules and the legal system, and the entrepreneurial incentives.

There is a strong relationship between corruption and firm performance and it's been one of the most discussed subjects in the corruption related researches. Corruption has a major impact on economic growth and the development of firms. There is evidence on previous research showed that corruption has positive effects on firm performance in general. These effects include: first, circumvent regulations and firm laws. Second, lower competition among firms. (Svensson, 2005) stated that" increased competition at the level of the official receiving the bribes may also reduce corruption". Third, increase In-efficiency and loss of the firm's resources.

(S.N.\& Sen, 2017) emphasis on "If the government is highly bureaucratic and corrupt, the returns on potential investments will be low and uncertain, and one would not expect much accumulation and growth in these environments". Transaction costs associated with regulations, weak institutions reflect resources diverted from production may also have significant implications for Firm performance.

Corruption presence deeper factors related to the system of authority and accountability in the organizational structure through which authority is exercised. Therefore, targeted treatment will not succeed if it is not aimed at reforming the structural factors inherent in building authority and 
The Effect of Corruption and Anti-Corruption on Firm Performance

Dr. HEBA KAMAL ELQASSABY ATALLAH

accountability within the organization (Alshamary \& Loai, 2011).

(Friesenbichler \& Peneder,2016) found that "large firms and firms with few competitors were statistically more likely to see corruption as favorable on Firm performance. Indeed, the joint marginal impact of changing from a competitive market with only small firms to an oligopoly/monopoly market with only large firms was to roughly double the probability of perceiving corruption as favorable". These results provide important and critical information about how government policy can attack and break down systematic corruption.

Modern societies, as well as ancient societies such as Egypt, Greece, Rome, have been fighting corruption. Different economic systems such as capitalism, communism, and feudalism as well as some religious parties (Muslim, Christian, and Buddhist) have been varying the degree of corruption but all agree on its negative effects (Nunkoo, et.al, 2018).

Many researchers studied, describe, and understand the organizational settings in which corruption takes place. They study whether one or several members within an organization, individuals on behalf of organizations, or entire organizations in cases where corruption operates as an institutionalized practice (Pinto et al., 2008).

According to (Ashforth \& Anand, (2003), Scholars who studied organization have confirmed that corruption should not 
The Effect of Corruption and Anti-Corruption on Firm Performance

Dr. HEBA KAMAL ELQASSABY ATALLAH

be treated as a state of misused but treated as a process too. Institutional misbehavior highly contributed to legitimate behaviors and push others in society to accept this as a norm and this what can be called corruption culture.

According to (Tabrizinia, 2016), Researches on business ethics introduced many insights into organizational efforts to eliminate corruption but has failed to found relationships between organizational environments, organizational behaviors, organizational outcomes, and organizational infrastructure.

Anti-corruption has several significant factors that have a positive effect on eliminating corruption actions in the firms and enhance its performance:

1. Ensuring Basic Human Rights: According to (Lambsdorff, (2007) Corruption, especially grand corruption, has enormous implications, both direct and indirect, for the enjoyment of human rights. Corruption undermines and violates a wide array of economic, social and cultural rights, including the right to development. Once human rights ensured, there will be no negative impact of corruption on firm or employees.

2. Active accountability and justice.

3. Less discrimination: Increased gender equality is one important factor behind getting corruption under control. When a class, gender, and race inequality present in any organization, productivity and performance will decrease (Rothstein, 2017). 
The Effect of Corruption and Anti-Corruption on Firm Performance

Dr. HEBA KAMAL ELQASSABY ATALLAH

4. Working with integrity and honesty: Lack of integrity is the root cause of corruption. Integrity is a personal/ individual choice which is exemplified by honesty and consistency in doing what is right according to the individual's values, beliefs, and principles, even when no one is watching.

5. Having honest competition: Dishonest, less well-organized competition within the firm "between employees" or with another firm in the industry will lead to having corruption.

6. Anti-corruption awareness: Government and firms' management should increase the awareness of the negative impacts of corruption not only on firm performance but on individuals too.

7. Mechanisms to control corruption: Enforcement of the four anti-corruption mechanisms: responsibility, accountability, transparency, and integrity plays a significant role in controlling corruption.

8. Effective personnel system to detect corruption: There are few actions that control corruption and enhance clean and healthy working environment. Managers and staff work together to plan, monitor and review goals, Managers understand their employees' skill sets and proficiency levels as well as having fair action toward their employees. Also, engaging employees and have them understand their responsibilities will enhance efficiency. Implement a good performance management system will align strategic business 
The Effect of Corruption and Anti-Corruption on Firm Performance Dr. HEBA KAMAL ELQASSABY ATALLAH

goals with employee performance, ensuring all staff members receive accurate and impartial performance feedback (Mone \& London, 2018).

9. Transparency: According to (Nunkoo, et.al, 2018), transparency refers to the extent to which an entity reveals information about its own decision-making processes, procedures, functioning, and performance. The degree of transparency is the extent to which an organization allows people to monitor its performance and participate in its policy decision-making. Greater transparency enhances the performance of the firm, however, transparency by its self is not enough to control corruption.

\section{RESEARCH METHODOLOGY}

In this section, the researcher presents the research methodology. It includes a discussion of the importance of the research, the research questions, the objectives of the research, and the hypothesis of the research. In addition, this section involves a discussion of the population and sample that were used for the research, the collection of data, and finally the data analysis.

\subsection{The significance of The Research}

There are many types of research on corruption and anticorruption and its impacts on firm governance, development, and success. Many pieces of research investigate the effects of 
The Effect of Corruption and Anti-Corruption on Firm Performance

Dr. HEBA KAMAL ELQASSABY ATALLAH

corruption on a country and political levels. This research investigates the effects of corruption and anti-corruption on Firm performance. This research specifically concentrates on effects of types and causes of corruption along with factors and dimensions of anti-corruption on firm performance determinants and factors. This research also looks at anti-corruption and its effect of Firm performance. This study will be interesting for researchers who are looking for a better understanding of the impacts of these corruption factors on firm performance in general.

This research is helpful for organizations and business that seek to have free corrupted environment by having knowledge of what causes corruption and how to decrease its impacts on the major firms' determinants. This study had concluded the most characteristics and consequences of corruption not only on firm market value and growth but also on the firm's most valuable resource: the human capital. This research also helpful for organizations who seek to increase their anti-corruption awareness by investigating significant factors and dimensions of anti-corruption and how it can play an important role in combating corruption.

\subsection{Research Question}

The real damage to a society occurs when entire generations of youth are mis-educated The costs and consequences of corruption The most direct, and in some ways the most inconsequential, cost of corruption is the waste of the 
The Effect of Corruption and Anti-Corruption on Firm Performance

Dr. HEBA KAMAL ELQASSABY ATALLAH

financial resources that get misdirected. The more serious costs are incurred when (a) children unable to afford bribes are denied access to schooling, (b) talent is misallocated due to promotion being awarded on the basis of bribery rather than merit, and (c) a generation of children come to believe that personal effort and merit do not count and that success comes through manipulation, favoritism and bribery. When corruption is so pervasive that it comes to be viewed as a basic mechanism of social and economic interaction, it instills a value that is highly destructive to social and economic development of a country. At the school level, corruption tends to center on bribes from parents to ensure student access, good grades, grade progression, and graduation. However, it also takes the form of teacher absenteeism, teachers collect salaries but the intended instruction does not occur, and create the need for private tutoring, or take salaries for work not actually done

From the above mentioned and from the results of the previous studies on corruption and Firm performance, the main purpose of this research focuses on answering the following questions:

1. What forms are corruption and ant-corruption take in in private international school group in Dhahran city?

2. Is there a relationship between corruption and firm performance?

3. Is there a relationship between anti-corruption, and firm performance? 
The Effect of Corruption and Anti-Corruption on Firm Performance Dr. HEBA KAMAL ELQASSABY ATALLAH

4. what are the effects of corruption and anti-corruption on firm performance?

\subsection{Research Objectives}

The research attempts to achieve the following objectives:

1. Measure corruption and anti-corruption practices and firm performance in private international school group in Dhahran city.

2. Find the relationship between corruption and firm performance.

3. Find the relationship between anti-corruption and firm performance.

4. Investigate if corruption has an effect on firm performance.

5. Investigate if anti-corruption has an effect on firm performance.

\subsection{Research Hypothesis}

Based on the research objectives mentioned earlier, the researcher proposes the following research hypothesis:

\section{Hypothesis 1}

- There is no significant relationship between corruption and firm performance.

- There is no significant relationship between anticorruption and firm performance.

\section{Hypothesis 2}

- There is no significant effect between corruption and firm performance. 
The Effect of Corruption and Anti-Corruption on Firm Performance

Dr. HEBA KAMAL ELQASSABY ATALLAH

- There is no significant effect between anti-corruption on firm performance.

\subsection{Research Questionnaire and Data Collection}

In order to examine the effect of corruption and anti-corruption on firm performance, A questionnaire was developed by the researcher to be distributed, a Likert scale used to measure the responses, which use 5-point responses scale ranging from 1 (strongly disagree) to 5 (strongly agree) which covered 35 main points on corruption and anti-corruption and Firm performance. A 5 Likert scale has been used to measure the responses, which use 5-point responses scale ranging from 1 (strongly disagree) to 5 (strongly agree).

The questionnaire included three sections in the same form. The first section was developed to measure corruption with 12 statements to test ( bribery, extortion, fraud, embezzlement, nepotism, cronyism, appropriation of public assets and property for private use, and influence peddling), The second section was developed to measure Anti-corruption with 11 statements to test ( Anti-corruption awareness, ensuring basic human rights ,mechanisms to control corruption, effective personnel system to detect corruption, transparency, Active accountability and justice, working with integrity and honesty, less discrimination, applying code of ethics and employees empowerment). The third section was developed to measure firm performance with 12 statements to test, (employees' satisfaction, customers' satisfaction, 
The Effect of Corruption and Anti-Corruption on Firm Performance

Dr. HEBA KAMAL ELQASSABY ATALLAH

maximize the wealth of stakeholders, operation effectiveness, operation efficiency, and quality of services. questionnaire conducted through monkey survey and with results of 151 responses within 5 days. The questionnaire helped the participants to understand corruption and its forms as well as the importance of the anti-corruption role in combating corruption. It's also highlighted the main firm performance factors that might get impacted by corruption. Questionnaires were organized in a way participants can move from one state to another in a smooth transition.

\subsection{Population and Sample}

The data of the research was collected from participants who work in a private International School Group in Dhahran using simple random sampling. Most participants were full-time employment $(n=146,97 \%)$, most aged between 25 and 44 $(n=115,76 \%)$. Most of the participants had years of experience between 11 and 20 years $(n=46,30 \%)$ and $58 \%$ of them had a bachelor's degree. The total number of population is 325 and the survey was distributed among 200 employees and received 151 responses. The percentage of responses for my sample was $85.32 \%$. The sample size has been calculated by using the following equation:

$\mathbf{x}=\mathbf{Z}(\mathbf{c} / \mathbf{1 0 0}) 2 \mathbf{r}(\mathbf{1 0 0}-\mathbf{r}) \mathbf{n}=\mathbf{N} \mathbf{x} /(\mathbf{N}-1) \mathrm{E} 2+\mathrm{x}) \mathrm{E}=\operatorname{Sqrt}[(\mathbf{N}-\mathbf{n}) \mathbf{x} / \mathbf{n}(\mathbf{N}-1)]$

The population size was 325 and the response distribution was $50 \%$ with recommendation sample size of 177 . 
The Effect of Corruption and Anti-Corruption on Firm Performance Dr. HEBA KAMAL ELQASSABY ATALLAH

Table (1) Number of Employees in The International Schools GroupDhahran

\begin{tabular}{|c|c|}
\hline Administrators/Directors & 18 \\
\hline Support Staff/ Managers & 95 \\
\hline Teachers/ Educators & 212 \\
\hline Total Number & 325 \\
\hline
\end{tabular}

Source: International School Group Website.

\subsection{Data Analysis}

In this research two statistical methods used to analyze the study data result, the methods used are:

1. Pearson Correlation: (for the purpose of measuring the strength and direction of the relationship between corruption and firm performance, and the relationship between anti-corruption and firm performance, the researcher used Pearson Correlation Analysis).

2. Multiple Linear Regression: (for the purpose of measuring the effect of corruption on firm performance and the effect of anti-corruption on firm performance, the researcher used Multiple Linear Regression).

\section{THE STATISTICAL ANALYSIS}

\subsection{Pearson Correlation}

In this section, for the purpose of measuring the strength and direction of the correlation relationship between corruption and 
The Effect of Corruption and Anti-Corruption on Firm Performance

Dr. HEBA KAMAL ELQASSABY ATALLAH

anti-corruption and firm performance, the researcher used Pearson Correlation.

Table (2) the relationship between corruption and anti-corruption and firm performance

\begin{tabular}{|ll|c|c|c|}
\hline & Corruption & $\begin{array}{c}\text { Anti- } \\
\text { Corruption }\end{array}$ & $\begin{array}{c}\text { Firm } \\
\text { performance }\end{array}$ \\
\hline Corruption & $\begin{array}{l}\text { Pearson } \\
\text { Correlation }\end{array}$ & 1 & $.506^{* *}$ & $.127^{* *}$ \\
\hline $\begin{array}{l}\text { Anti- } \\
\text { Corruption }\end{array}$ & $\begin{array}{l}\text { Pearson } \\
\text { Correlation }\end{array}$ & $.506^{* *}$ & 1 & $.718^{* *}$ \\
\hline $\begin{array}{l}\text { Firm } \\
\text { performance }\end{array}$ & $\begin{array}{l}\text { Pearson } \\
\text { Correlation }\end{array}$ & $.127^{* *}$ & $.718^{* *}$ & 1 \\
\hline
\end{tabular}

**. Correlation is significant at the 0.01 level (2-tailed).

Hypothesis 1: corruption and firm performance:

$\mathbf{H}_{\mathbf{0}}$ : There is no significant relationship between corruptions and firm performance.

$\mathbf{H}_{1}$ : There is a significant relationship between anti corruptions and firm performance.

The results of $((\mathrm{p}$-value $=.0 .000<0.01), \mathrm{r}=0.127)$ indicated that there was a significant low relationship between corruptions and firm performanceso that $\mathrm{H} 1$ is accepted.

Hypothesis 1: anti-corruption and firm performance:

H0: There is no significant relationship between anti-corruption and firm performance. 
The Effect of Corruption and Anti-Corruption on Firm Performance

Dr. HEBA KAMAL ELQASSABY ATALLAH

H1: There is a significant relationship between anti-corruption and firm performance.

The results of $((\mathrm{p}$-value $=.0 .000<0.01), \mathrm{r}=0.718)$ indicated that there was a significant strong relationship between anticorruption and firm performance so that $\mathrm{H} 1$ is accepted.

\subsection{Multiple Linear Regression}

In this section, the researcher has used multiple linear regression analysis for the purpose of examining the statistical implications of the research hypotheses. In addition, this analysis helped the researcher to measure the effect of corruption and anti-corruption on firm performance, and the direction of that effectiveness, see tables ( 3 and 4 ).

Table (3) Multiple Linear Regression for measuring the effect of corruption and anti-corruption on firm performance.

\begin{tabular}{|c|c|c|c|c|}
\hline Model & $\mathrm{R}$ & R Square & Adjusted R Square & $\begin{array}{c}\text { Std. The error of } \\
\text { the Estimate }\end{array}$ \\
\hline 1 & .721 & .521 & .514 & .42395 \\
\hline
\end{tabular}

Table (3) displays the regression analysis for the corruptions and anti-corruption (as independent variable), and firm performance (as dependent variable) $\mathrm{R}=.721$ means that there is a strong relationship between the independent variables (corruptions and anti-corruption) was affecting the dependent variable (firm performance), and since The coefficient of determination $\mathrm{R}$ square $=0.521$ that means the affecting rate of corruptions and anti-corruption on firm performance as (52\%). 
The Effect of Corruption and Anti-Corruption on Firm Performance

Dr. HEBA KAMAL ELQASSABY ATALLAH

Table (4) the results of regression analysis for the effect of corruptions and anti-corruption and firm performance

\begin{tabular}{||c|c|c|c|c|c|}
\hline \multirow{2}{*}{ Model } & \multicolumn{2}{|c|}{$\begin{array}{c}\text { Unstandardized } \\
\text { Coefficients }\end{array}$} & $\begin{array}{c}\text { Standardized } \\
\text { Coefficients }\end{array}$ & & \\
\cline { 2 - 4 } & $\mathrm{B}$ & Std. Error & Beta & $\mathrm{t}$ & Sig. \\
\hline (Constant) & 1.347 & .177 & & 7.597 & .000 \\
\hline Corruptions & .063 & .049 & .085 & 1.289 & .199 \\
\hline anti-corruptions & .585 & .057 & .675 & 10.223 & .000 \\
\hline
\end{tabular}

a. Dependent variable: Firm performance

According to Table (4), beta coefficient of the corruption and anti-corruption are .063 and $.585, t=1.289$ and $t=10.223$, the result means that there is a significant relationship between anticorruption and firm performance since p.value $=0.000$. the result means that there is no significant relationship between corruption and firm performance since p.value $=.199$.

\section{Hypothesis 2}

- There is no significant effect of corruption on firm performance.

- There is no significant effect of anti-corruption on firm performance.

Hypothesis 2 has predicted that there is no significant effect of corruption and anti-corruption on firm performance, the researcher used Multiple Linear Regression analysis and found that there is a significant effect of anti-corruption on firm performanceand also found that there is no significant effect of corruption on firm performance. Therefore, hypothesis 2 is accepted in the part of there is no significant effect of corruption 
The Effect of Corruption and Anti-Corruption on Firm Performance

Dr. HEBA KAMAL ELQASSABY ATALLAH

on firm performance. and hypothesis 2 is rejected in the part of there is no significant effect of anti-corruption on firm performance.

\section{RESULTS AND RECOMMENDATIONS.}

\subsection{Results}

1. The results of $((\mathrm{p}$-value $=.0 .000<0.01), \mathrm{r}=0.127)$ indicated that there was a significant low relationship between corruptions and firm performance which is agreed with (Dreher, et.al, 2005).

2. The results of $((\mathrm{p}$-value $=.0 .000<0.01), \mathrm{r}=0.718)$ indicated that there was a significant strong relationship between anti-corruptions and firm performance which is consistent with Treisman (2000) findings.

3. The correlation coefficient $(\mathrm{R}=.721)$ that tells how strongly the independent variables (corruptions and anticorruption) was affecting the dependent variable (firm performance), and since $(\mathrm{R}$ square $=0.521)$ that means the affecting rate of corruptions and anti-corruption on Firm performance was $(52 \%)$.

4. The results from the table (4) gave us the coefficients of the linear equation only for the significant coefficients anti-corruption since p.value $=0.000$. 
The Effect of Corruption and Anti-Corruption on Firm Performance Dr. HEBA KAMAL ELQASSABY ATALLAH

5. The overall statistical analysis shows that the effect of corruption on firm performance is moderate because of the positive effect of anti-corruption on firm performance.

6. Finally, the study shows that there is no significant effect of corruption on private firm performance which is not consistent with the previous researches findings which showed that corruption has positive effects on firm performance in general Lambsdorff (2005), Angela, (2016), Nunkoo, et.al, (2018) and Rothstein, 2017). the study also showed a strong relation between anticorruption and firm performance which consistent with what Nunkoo, et.al, (2018) found.

\subsection{Recommendations}

- Since the overall statistical analysis showed that the effect of corruption on Firm performance is moderate because of the positive effect of anti-corruption on firms, managers and officials should invest more time in anti-corruption awareness and efforts such as raising the basic human rights and values like dignity, fairness, equality, respect, and independence.

- Managers and officials should also invest more time on enforcement the four anti-corruption mechanisms: responsibility, accountability, transparency, and integrity since they play a significant role in controlling corruption. 
The Effect of Corruption and Anti-Corruption on Firm Performance

Dr. HEBA KAMAL ELQASSABY ATALLAH

- Managers and officials should also, adopt effective personnel system to detect corruption through involving employees in every business aspects and have them understand their responsibilities and ensuring all staff members receive accurate and impartial performance feedback will enhance operation efficiency which leads to improve Firm performance as results showed.

- Managers and officials should reward integrity and honesty behaviors because it has a good impact on Firm performance according to literature review and statistical analysis.

- According to this study's literature review and statistical analysis, it is important to implement clear code of conduct to enhance professionalism and control corrupted behaviors for example a "teachers" code of conduct. Teachers who violate it can lose their teaching license.

- These are some of the significant factors to combat corruption within the organization: secure basic human rights, Also, discourage discrimination practices inside the work place to avoid any related corruption behaviors.

- attention should first be paid to diagnosing rather than redressing any type of corrupt forms, adopting prevention rather than punishment, informal rather than formal approaches, and situational norms rather than formalized legislation. The protection of students and employees in 
The Effect of Corruption and Anti-Corruption on Firm Performance

Dr. HEBA KAMAL ELQASSABY ATALLAH

education sector from corruption should be a priority throughout all levels of education firms.

\subsection{Limitations and Future Research}

This research has encountered the following limitations.

- Although the data is considered to be appropriate for the quantitative analysis, the sample size was small. More data was going to provide clearer trends and more discrete effects.

- The study was applied to a private international schools, and the results of the study was limited to the sample of privet sector. for future research, the researcher is suggested to apply this study on a governmental education sector the results could provide more distinct effect and clearer relationships.

- Since the survey was sent in a digital format, there is no clear picture of the name of schools that were included in the study. For future research, the researcher is suggested to get a report from the schools that participated and responded to the survey.

- Finally, the amount of survey questions was too much that made some of the employees to avoid participating in responding to the survey. For future research, researcher can reduce the questions by omitting the questions that are 
The Effect of Corruption and Anti-Corruption on Firm Performance

Dr. HEBA KAMAL ELQASSABY ATALLAH

close in nature and would not affect the final result of the survey.

\subsection{Conclusion}

In conclusion, this research aimed to examine the relationship and effect of corruption and anti-corruption on Firm performance, in an attempt to discusses the pervasive corruption forms that corruption takes within the privet education sector in school level, and interventions as anticorruption practices that have been suggested for reducing corruption. The results indicated that there is a significant moderate relationship between corruptions and Firm performance, the results also indicated that there was a significant strong relationship between anti-corruption and Firm performance. and the results showed that there is no significant effect of corruption on Firm performance while there is a strong significant effect of ant-corruption on firm's performance, the explanation for that, in privet international schools there is a close monitoring of performance by the top management leaders, which is the basis for the success of any system. the quality of top leadership. leaders who respect the rule of law, emphasize transparency in the operation of the offices they oversee, take action against subordinates found violating rules, and exhibit integrity in their own transactions can make a 
The Effect of Corruption and Anti-Corruption on Firm Performance Dr. HEBA KAMAL ELQASSABY ATALLAH

difference. Honest leaders can be a powerful force in reducing corruption. Unfortunately, this situation does not exist in governmental schools, where performance control is neglected and many forms and practices of corruption spread in the most important sector at all, the education sector, which produce good citizens who are respect law, human rights and fairness. Consequently, fighting against corruption following strong anti-corruption practices in all kinds of education sectors, should be given a top priority because the most important change that is required today is to reform the education sector. 
The Effect of Corruption and Anti-Corruption on Firm Performance

Dr. HEBA KAMAL ELQASSABY ATALLAH

\section{References}

Adetunji, O. M., \& Owolabi, A. A. (2016), Firm performance and Its Drivers: How Important Are the Industry and Firm-Level Factors? International Journal of Economics and Finance, Vol.8, No.11, p. 60.

Alshamary, M. \& Loai, M. (2010), The Efforts of Kingdom of Saudi Arabia in The Area of Integrity and Anti-Corruption. Retrieved https://repository.nauss.edu.sa/bitstream/handle/123456789/56305/\%D8 $\%$ AC\%D9\%87\%

Al-Tit, A. A. (2017), Factors affecting the organizational performance of manufacturing firms. International Journal of Engineering Business Management. https://doi.org/10.1177/1847979017712628.

Angela Barkhouse, Hugo Hoyland \& Marc Limon (2016), Corruption: a human rights impacts assessment. University rights group.

Ashforth, B.E. \& V. Anand (2003) 'The normalization of corruption in organizations', Research in Organizational Behavior, Vol.25, pp. 1-52.

Bennet, Nicholas. Corruption in education systems in developing countries: What is it doing to the Young.

Bertot, J. C., Jaeger, P. T., \&amp; Grimes, J. M. (2010), Using ICTs to create a culture of transparency: E-government and social media as openness and anti-corruption tools for societies. Government information quarterly, Vol.27, No.3, pp. 264-271.

Bransten, J. (2001), World: Corruption said to be flourishing in Education. Radio Free Europe.

Chilton, B. S. (2005), A complex systems model for understanding the causes of corruption: Case study-turkey (Doctoral dissertation, University of North Texas).

Combating Corruption. (2018), The World Bank. 
The Effect of Corruption and Anti-Corruption on Firm Performance

Dr. HEBA KAMAL ELQASSABY ATALLAH

Dabbous, S., \& Dimant, E. (2018), 2. Causes and effects of corruption: new developments in empirical research. Handbook on the Geographies of Corruption, p.15.

Das, N. (n.d.). Anti-Corruption. United Nations Global Compact.

Di Tella, R. and Schargrodsky. (2002), Controlling corruption through high wages. http://www.people.hbs.edu/rditella/papers/high_wages.pdf.

Dreher, A., Kotsogiannis, C., \& McCorriston, S. (2005), Corruption around the World: Evidence from a Structural Model, University of Konstanz and University of Exeter. mimeo.

Enste, D. H., \& Heldman, C. (2018), The consequences of corruption. Handbook on the Geographies of Corruption, p.106.

Friesenbichler, K., \& Peneder, M. (2016), Innovation, competition and productivity, Economics of Transition, Vol. 24, No. 3, pp.535-580.

Gavrea, Corina \& Ilies, Liviu \& Stegerean, Roxana. (2007), Determinants of organizational performance: The case of Romania. Management \& Marketing.Vol. 6.

Hindess, B. (2012), Introduction: How should we think about corruption?

In Corruption: expanding the focus. ANU ePress.

http://www.10iacc.org/content.phtml?documents=112\&art=126

https://doi.org/10.1007/s11187-016-9802-

https://doi.org/10.1111/ecot.12100

Jiménez-Jiménez, D., \& Sanz-Valle, R. (2011), Innovation, organizational learning, and performance. Journal of business research, Vol.64, No.4, pp.408-417.

Johnston, M. (1996), The search for definitions: the vitality of politics and the issue of corruption. International social science journal, Vol.48, No.149, pp.321-335. 
The Effect of Corruption and Anti-Corruption on Firm Performance

Dr. HEBA KAMAL ELQASSABY ATALLAH

Lambsdorff, J. G. (2007), 1 Causes and consequences of corruption: What do we know from a cross-section of countries? International handbook on the economics of corruption, 1.

Lambsdorff, Johann (2005), Consequences and causes of corruption: What do we know from a cross-section of countries? p.34.

Laxmi Narayan, (2014), Corruption in Education - Nature and

Causes,https://www.researchgate.net/publication/310461078

Lebas, M., \& Euske, K. (2007), A conceptual and operational delineation of performance. In A. Neely (Ed.), Business Performance Measurement: Unifying Theory and Integrating Practice, pp. 125-140. Cambridge: Cambridge University Press. doi:10.1017/CBO9780511488481.008

Mone, E. M., \& London, M. (2018), Employee engagement through effective performance management: A practical guide for managers. Routledge.

Nunkoo, R., Ribeiro, M. A., Sunnassee, V., \& Gursoy, D. (2018), Public trust in mega event planning institutions: The role of knowledge, transparency and corruption. Tourism Management, Vol.66, pp.155166.

Odusami, K. T. (2002), Perceptions of construction professionals concerning important skills of effective project leaders. Journal of Management in Engineering, Vol.18, No.2, pp. 61-67.

Parvin, M. M., \& Kabir, M. N. (2011), Factors affecting employee job satisfaction of pharmaceutical sector. Australian journal of business and management research, Vol.,1, No.9, p. 113.

Pinto, J., Leana, C. R., \& Pil, F. K. (2008), Corrupt organizations or organizations of corrupt individuals? Two types of organization-level corruption. Academy of Management Review, Vol.33, No.21, pp. 685709 . 
The Effect of Corruption and Anti-Corruption on Firm Performance

Dr. HEBA KAMAL ELQASSABY ATALLAH

Rose-Ackerman, S. (1998), Corruption and development. In Annual World Bank Conference on Development Economics 1997 (pp. 35-57). Washington DC: World Bank.

Rothstein, B. (2017). Gender equality, corruption and meritocracy.

S.N., R. R., \& Sen, K. (2017), Does Institutional Quality Matter for firm performance? Evidence from India. South Asia Economic Journal, Vol.18, No.2, pp.184-213. https://doi.org/10.1177/1391561417713126

Sahakyan \& Stiegert, (2012), (PDF) Corruption and Firm performance.

Available from:

https://www.researchgate.net/publication/260783172_Corruption_and_

Firm_Performance

Selvam, M., Gayathri, J., Vasanth, V., Lingaraja, K., \& Marxiaoli, S. (2016), Determinants of Firm performance: A Subjective Model. Int'1 J. Soc. Sci. Stud., Vol..4, No. 90.

Shinichiro Tanaka, (2001), Corruption in education sector development: A

suggestion for anticipatory strategy, International Journal of

Educational Management, Vol. 15, No.4.

Singh, H. (2006). The importance of customer satisfaction in relation to customer loyalty and retention. Academy of Marketing Science,Vol. 60, No.46. pp.193-225.

Sivathaasan, N., Tharanika, R., Sinthuja, M., \& Hanitha, V. (2013), Factors determining profitability: A study of selected manufacturing companies listed on Colombo Stock Exchange in Sri Lanka. European Journal of Business and management, Vol.5, No.27, pp. 99-108.

Svensson, J. (2005), Eight questions about corruption. Journal of economic perspectives, Vol.19, No.3.

Tanzi, V., (1998), Corruption around the world: Causes, consequence, scope and cures. IMF Staff Papers, Washington D.C.: International Monetary Fund. 
The Effect of Corruption and Anti-Corruption on Firm Performance

Dr. HEBA KAMAL ELQASSABY ATALLAH

Treisman, D. (2000), The causes of corruption: a cross-national study. Journal of public economics, Vol.76, No.3, pp.399-457.

U Myint, (2000), Corruption: Causes, Consequences and Cures, AsiaPacific Development Journal, Vol. 7, No. 2.

Ugaz, J. \& Panfilova, E. (2016), Grand Corruption. Transparency International. Retrieved From https://youtu.be/SyU8Wss6j3c

Wang, E., Chou, H. W., \& Jiang, J. (2005), The impacts of charismatic leadership style on team cohesiveness and overall performance during ERP implementation. International Journal of Project Management, Vol.23, No.3, pp.173-180.

Wongrassamee, S., Simmons, J. E., \& Gardiner, P. D. (2003), Performance measurement tools: The Balanced Scorecard and the EFQM Excellence Model. Measuring business excellence, Vol.7, No.1, pp.14-29.

Wood, D. J. (1991), Corporate social performance revisited. Academy of management review, Vol.16, No.4, pp. 691-718.

Yang, J. S. (2017), The governance environment and innovative SMEs. Small Business Economics, Vol. 48, No.3, pp.525-541.

Yusof, M. N., \& Bakar, A. H. A. (2012), Knowledge management and growth performance in construction companies: a framework. ProcediaSocial and Behavioral Sciences, 62, 128-134.

Zhining Wang, Nianxin Wang,\& Huigang Liang, (2014), Knowledge sharing, intellectual capital and Firm performance, Management Decision, Vol. 52 Issue: 2, pp.230-258, https://doiorg.sdl.idm.oclc.org/10.1108/MD-02-2013-0064 